\title{
Gastropods Diversity in Thondaimanaru Lagoon (Class: Gastropoda), Northern Province, Sri Lanka
}

\section{Amarasinghe Arachchige Tiruni Nilundika Amarasinghe, Thampoe Eswaramohan, Raji Gnaneswaran}

Department of Zoology, Faculty of Science, University of Jaffna, Jaffna, Sri Lanka

Email: tiruni1991@gmail.com

How to cite this paper: Amarasinghe, A. A. T. N., Eswaramohan, T., \& Gnaneswaran, R. (2021). Gastropods Diversity in Thondaimanaru Lagoon (Class: Gastropoda), Northern Province, Sri Lanka. Journal of Geoscience and Environment Protection, 9, 21-30.

https://doi.org/10.4236/gep.2021.93002

Received: January 25, 2020

Accepted: March 9, 2021

Published: March 12, 2021

Copyright $\odot 2021$ by author(s) and Scientific Research Publishing Inc. This work is licensed under the Creative Commons Attribution International License (CC BY 4.0).

http://creativecommons.org/licenses/by/4.0/

\begin{abstract}
Thondaimanaru lagoon (TL) is one of the three lagoons in the Jaffna Peninsula, Sri Lanka. TL (N-9.819584, E-80.134086), which is $74.5 \mathrm{Km}^{2}$. Fringing these lagoons are mangroves, large tidal flats and salt marshes. The present study is carried out to assess the diversity of gastropods in the northern part of the TL. The sampling of gastropods was performed by using quadrat method from July 2015 to June 2016. Different sites were selected and rainfall data, water temperature, salinity of the water and GPS values were collected. Collected gastropod shells were classified using standard taxonomic keys and their morphological as well as morphometrical characteristics were analyzed. A total of 23 individual gastropods were identified from the lagoon which belongs to 21 genera of 15 families among them 11 gastropods were identified up to species level.
\end{abstract}

\section{Keywords}

Biodiversity, Quadrat Sampling, Conservation, Human Impact

\section{Introduction}

Investigation of lagoon gastropod diversity in Thondaimanaru, Northern Province Sri Lanka from July 2015 to June 2016. Water chemistry did differ between fish landing sites and undisturbed habitats at some sampling times, indicating that differences due to human impact do exist, but these are dependent on periods of calm weather (Bae \& Park, 2020). Thondaimanaru was not much used for researches recently especially on gastropod diversity except the recent studies carried out by Department of Zoology in University of Jaffna under IUCN/MFF 
project. It is very important to implement research work here as a new research place for gastropod diversity. Due to the present natural beauty and the arrival of migratory birds to TL, it is an ideal place for tourists. Those migratory birds are using the lagoon as their lodgment during the migration and those migrants respond to weather and stop over habitat quality as well as the foraging behavior of the migrants. Among their precious feeds, gastropods are the major source of foods for migrants. Such as mud creepers, Ceriths, whelks and periwinkles. Also the existence of gastropods in the lagoon provides a better support for the nutrient recycling, especially within the mangrove area. As they have different feeding habits such as detritivores, filter feeders, herbivores, carnivores and omnivores, they are showing higher abundance and diversity within the lagoon area. Hence it deserves our attention towards the lagoon as a better research place for gastropod diversity.

The main objectives of this study were: collection of the gastropod shells from Thondaimanaru lagoon by selecting different five sites, clean and identify (classification) them up to genus/species level through running taxonomic keys and preserve the shells for future studies. Here the present survey expects to discover more inhabit gastropod species within the area and the resultant data can be used to get an idea about the biodiversity within lagoon gastropods.

\section{Literature Review}

Different estimates for aquatic gastropods in class Gastropod, phylum Mollusca, kingdom Animalia give about 30,000 species of marine gastropods all over the world. And about 240 marine snail species with 28 families were reported in Sri Lanka (De Silva, 2006).

Mollusk are very important animals with a remarkable value in various ways, especially they are exploited for industrial, edible and ornamental purposes (Darwin \& Padmavathi, 2017). The marine shelled species of gastropods include edible species such as abalone, conches, periwinkles, whelks and numerous other sea snails that produce sea shells that are coiled in their adult stages though in some the coiling may not be very visible, for example in cowries. In a number of families of species, such as all the various limpets, the shell is coiled only in the larval stage, and is a simple conical structure after that.

Although the name "snail" can be applied to all the members of this class, commonly this word means only those species with a big external shell, that the soft parts can withdraw completely into it.

Those gastropods without a shell, and those with only a very reduced or internal shell, are usually known as slugs; and those with a shell into which they cannot withdraw are termed limpets.

Gastropods are among the few groups of animals to have become successful in all three major habitats; the ocean, fresh water and land. The importance of the marine gastropods can be described as a nutritious food source, pests, bird-food, involve in the maintenance of aquatic food chains. Mollusks occupy all food web 
levels of mangroves as hunters, herbivores, saprophages, and filter feeders (Moradi et al., 2019). Especially important in nutrient cycling within the mangrove ecosystems due to present high diversity of gastropods associated with mangroves (Dissanayake \& Chandrasekara, 2014). Especially Neritidae, Muricidae, Nassariidae and Ellobiidaefamilies are observed to be the dominant gastropod families in the mangrove ecosystems (Yadav et al., 2019).

Few species involve in the transmitting of animal diseases; the flukes can use gastropods as their intermediate host and cause human Schistosomiasis (Giannelli et al., 2016). Also some of them are scavengers that prefer to feed on dead plant or animal matter, others are predators, some are herbivores; feeding on algae or plant materials and a few species are external or internal parasites of other invertebrates. Some are living with their symbiotic partner. Their precious habitats that are supposed to observe are; Sea water, brackish water, mud flats, sand bars, estuaries, the rocky intertidal and the sandy sub tidal. Sandy beaches, sand stone beach reefs, rocky shores, coral reefs are the best places for gastropods to hide and Oliva sp., Conus sp., and cowries are such common inhabitants (Perera \& Weerakkody, 2004). But there are other places that are difficult to visit like hydrothermal vents in abyssal depths where they thrive well (Bieler, 1992). According to the research done by D. D. G. L. Dahanayaka, S. C. Jayamanne and M. J. S. Wijeyaratne, they could found several macro benthic communities such as crustaceans, polychaetes and bivalves including some species of gastropods in the Negombo lagoon (Dahanayaka \& Wijeyaratne, 2006). Also according to the survey done by biodiversity secretariat along the coastal areas in Sri Lanka found out several bivalves and gastropod species along the coastal areas in Negombo.

It is important to investigate gastropod diversity within natural ecosystems, because it reveals numerous information about the dynamic environment. Generally speaking, gastropods can act as bio-indicators for monitoring sediment and water quality (Wijeyaratne \& Kalaotuwawe, 2017) as they are among one of the sensitive animals in wetlands. Therefore the diversity of gastropod can be varied according to the present threats to the community. Basically those threats can be classified as natural and anthropogenic threats. Natural threats are due to unfavorable conditions of the environment and anthropogenic are man-made problems (Herath \& Gunasekara, 2013).

Attempts have been made to prevent sea water influx to Thondaimanaru and Upparu lagoon by constructing barrages across the lagoons with a view to convert them into fresh water bodies. And there is no any fresh water inflow from a riverine system into the lagoon. In Thondaimanaru lagoon, the Sri Lankan irrigation department established a barrage with sluice gates $400 \mathrm{~m}$ from the mouth of the lagoon. By collecting the rain water and lowering the salinity, the barrage transformed the lagoon's brackish water into fresh water. Architects of the barrage anticipated that collecting freshwater will slowly reduce the accumulated salt in the land around the lagoon, making the land less saline and suitable for crop production. Collecting fresh water for irrigation is also considered as a bonus (Piratheepa 
et al., 2016).

The plan was worked, salinity levels in the lagoon and ground water of nearby wells declined. Because of changes in water salinity levels the lagoon fauna and flora also changed. Also it will change the productivity of the ecosystem and effect on the species richness.

\section{Methodology}

During the survey, gastropod shells were collected by choosing five different sites (L1-L5) as explained in Figure 1. These sampling sites were selected from the mouth of the lagoon up to the freshwater body which is made by the barrage. Each sampling site (Figure 2) contains five plots inside $40 \mathrm{~m}^{2}(20 \mathrm{~m} \times 2 \mathrm{~m})$ of selected area. GPS, rainfall, water temperature and salinity in each site were measured. Samples were collected by using quadrat sampling $(0.5 \mathrm{~m} \times 0.5 \mathrm{~m})$ along the transect line (Suominen et al., 2003). Sampling occurred in the coastal area of the lagoon. Hand scoop was used to dig the sand/mud flats and then put them into a sieve by mixing with water and washed off sand and mud particles

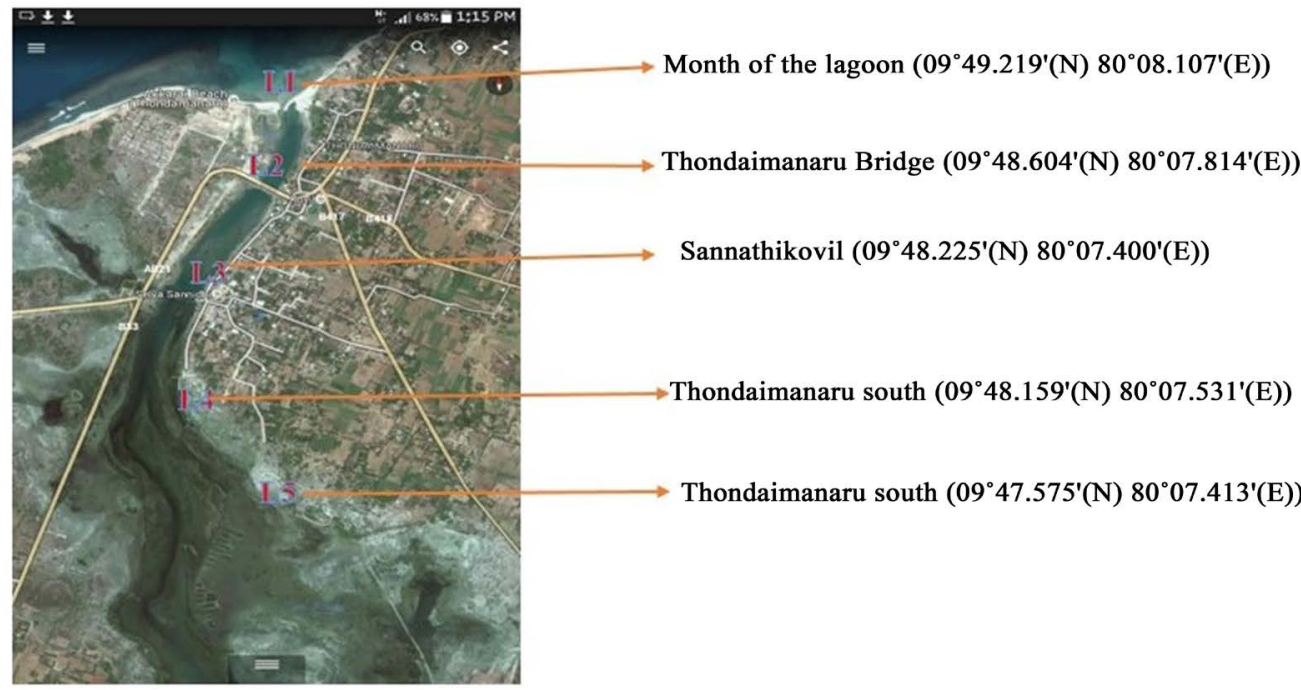

Figure 1. Map view of Thondaimanaru lagoon (adapted from Google map).

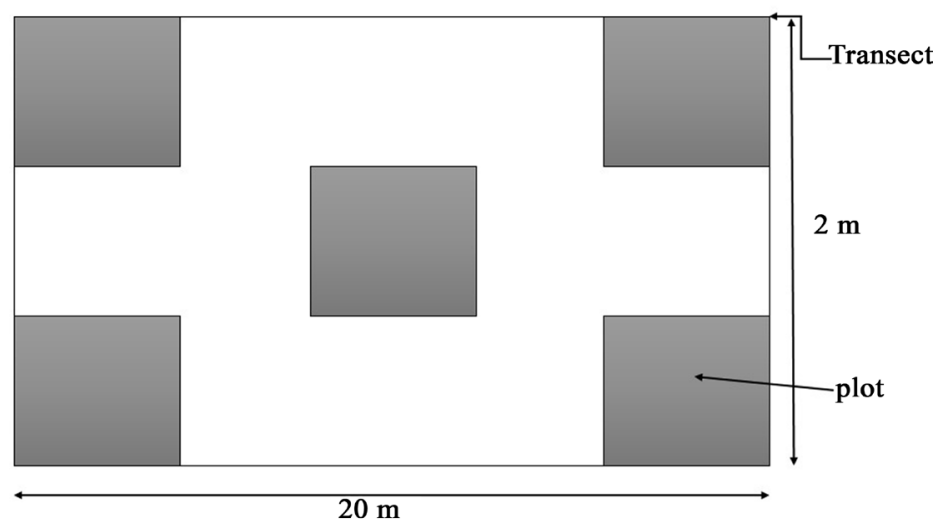

Figure 2. Structure of one sampling site. 
and then shells were picked up and placed them in separate vials/containers which have already labeled by the location symbol. (L1, L2, L3...). Then collected shells were kept in 70\% ethanol and keep them for 20 minutes to clean the shell well. All the cleaned shells were dried fully under the sun light for 48 hours. Then the shells are identified and classified up to genus/species level using taxonomic keys (Rosenberg, 1993). The fully dried shells are packed by polythene and labeled and sealed them properly. Every label contains the date of collection, location, collector name, classification up to genus/species level. The shells are preserved in a dry clean place in a proper arranged way for better observation and further studies.

\section{Results}

A total of 23 individual gastropods were identified from five selected sites of the lagoon which belongs to 21 genera of 15 families among them 11 gastropods were identified up to species level. The average temperature and the rainfall were $28.3^{\circ} \mathrm{C} \pm 0.8^{\circ} \mathrm{C}$ and $71.5 \pm 55 \mathrm{~mm}$ respectively in Thondaimanaru lagoon. Although the average salinity was $35.26 \pm 8.94 \mathrm{ppt}$, there are salinity gradient between the selected sites and the species distribution too varies accordingly.

\section{Discussion}

The composition and abundance of gastropod communities within different sites of the lagoon showed some differences as well as the similarities. Those differences due to their different water quality status (such as salinity), environmental factors such as rain fall and also human influences. As it has no inland water supply, Thondaimanaru is an isolated water body with an outlet to Indian Ocean from the Northern side of the Island. Due to the man-made barrier, rain water is retaining inside the lagoon body by preventing the saline water entrance. And it is expected to reduce the water salinity inside the lagoon. Here the pollution is very low when compares with the other lagoons in Sri Lanka. But above mentioned man-made barrier gave some effects on the diversity of the organisms in the lagoon. Early records showed the degradation of number of animal varieties within the lagoon by losing their usual living conditions after the construction of the barrier.

As the final outcome of this research project, 15 gastropod families could be reported within the Thondaimanaru lagoon with 11 species of gastropods could identify up to species level among the 23 individual gastropods. Gastropod family, subfamily, genus or species have been presented through Table 1 . Some of the gastropods have been identified up to species level such as Cerithidea cingulata, Terebralia palustris, Cerithium obeliscus, Nassarius pullus, Tonna sulcosa, Conus ceylanensis, Murex indicus, Oceanida graduata, Clithon oualaniense, Littoraria undulata, Turbinella pyrum. Family Potamididae, Eulimidae and Littorinidae show high species richness than other families.

Gastropod shells were classified according to a taxonomic key and their 
Table 1. Observed and collected gastropod species from Thondaimanaru lagoon.

\begin{tabular}{|c|c|c|}
\hline Class gastropod; Family & Subfamily & Genus/species \\
\hline & & Cerithidea cingulata \\
\hline \multirow[t]{2}{*}{ Potamididae } & & Cerithidea sp. \\
\hline & & Terebralia palustris \\
\hline Cerithiidae & & Cerithium obeliscus \\
\hline Nassariidae & Nassariinae & Nassarius pullus \\
\hline Tonnidae & & Tonna sulcosa \\
\hline Conidae & & Conus ceylanensis \\
\hline \multirow[t]{3}{*}{ Muricidae } & Muricinae & Murex indicus \\
\hline & Muricinae & Dermomurex \\
\hline & & Ocenebra sp. \\
\hline Strombidae & & Lambis sp. \\
\hline \multirow[t]{2}{*}{ Melongenidae } & & Volegalea sp. \\
\hline & & Melanella sp. 1 \\
\hline \multirow[t]{2}{*}{ Eulimidae } & & Melanella sp. 2 \\
\hline & & Oceanida graduata \\
\hline \multirow[t]{2}{*}{ Neritidae } & Neritinae & Clithon oualaniense \\
\hline & & Littoraria undulata \\
\hline \multirow[t]{2}{*}{ Littorinidae } & & Austrolittorina sp. \\
\hline & & Echinolittorina $s p$. \\
\hline Turbinellidae & Turbinellinae & Turbinella pyrum \\
\hline Olividae & Olivinae & Oliva sp. \\
\hline Ranellidae & Ranellinae & Halgyrineum $s p$ \\
\hline Turbinidae & & Turbo sp. \\
\hline
\end{tabular}

morphological differences were considered. Gastropods are different from each species basically due to their size, shape of the shell and colour (Fernando, 2009). Their sizes can be varied form microscopic to macroscopic. Some Oliva $s p$. present in Figure 3, some Cerithidea sp. And Oceanida sp. present in Figure 4 and Melanella $s p$. In Figure 5 are tiny gastropod species recorded during this survey and their body whorls' lengths were less than a $1 \mathrm{~cm}$. But Tonna in Figure 5, Lambis, Turbinella and Volegalea in Figure 3 and Terebralia in Figure 4 are the largest specimen those found at the Thondaimanaru lagoon. Most of them are larger than $5 \mathrm{~cm}$. their shapes also can be varied as horn shape, tower shape, cone shape, baby ear shape, cap shape, button shape and bean shape. As in Figure 3, Conus are cone shaped while Clithons are baby ear shape. In Figure 4, Cerithidea are tower shaped and in Figure 3 Oliva is bean shaped. According to the presence of different colours and colour patterns also gastropod shells can be classified. In Figure 3, Clithon shows variety of colours and colour bands on the shell. And some of the shells have spines on the body whorl such as Murex 


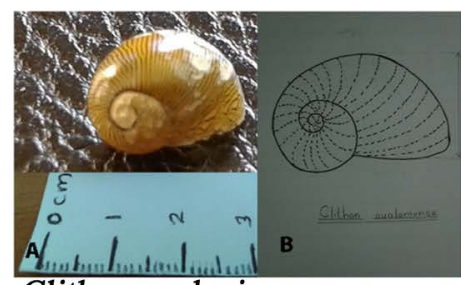

Clithon oualaniense

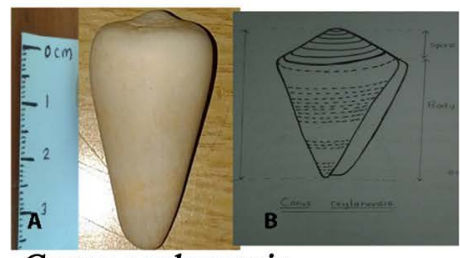

Conus ceylanensis

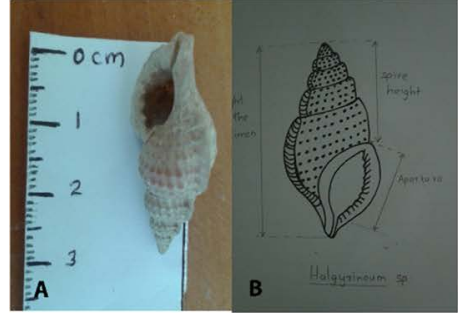

Halgyrineum $s p$.

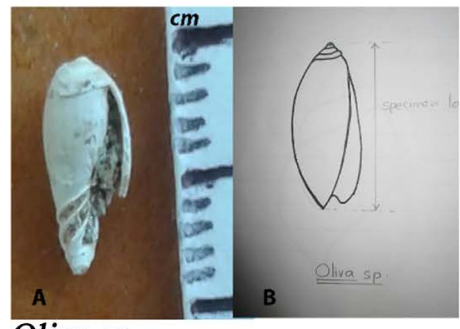

Oliva sp.

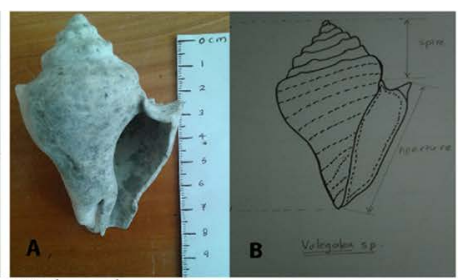

Volegalea sp.

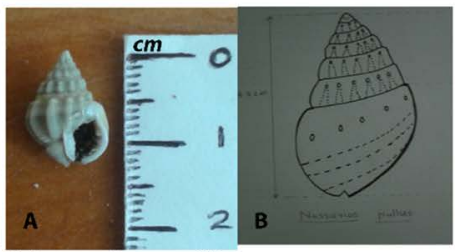

Nassarius pullus

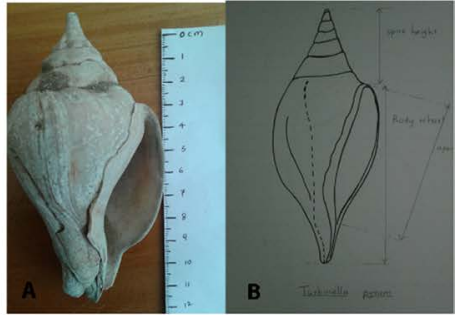

Turbinella pyrum

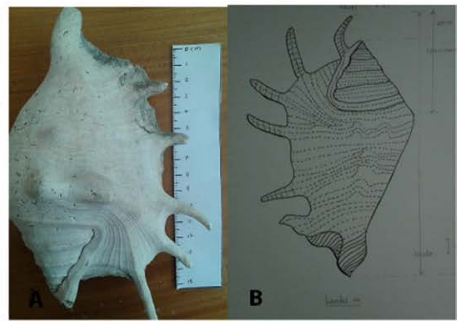

Lambis $s p$.

Figure 3. Collected gastropod species within the Thondaimanaru lagoon, (A) Photographic view, (B) Diagramatic view.

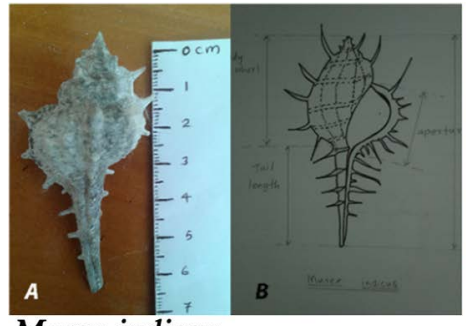

Murex indicus

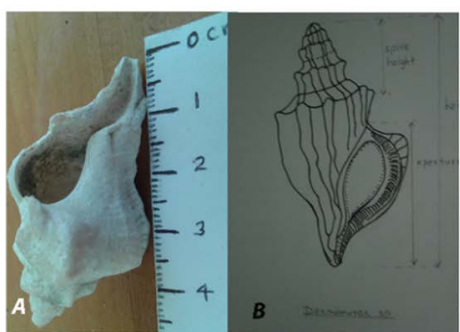

Dermomurex $s p$.

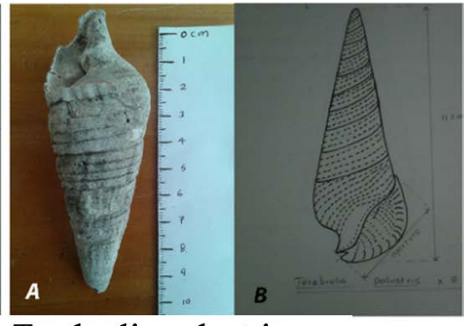

Terebralia palustris

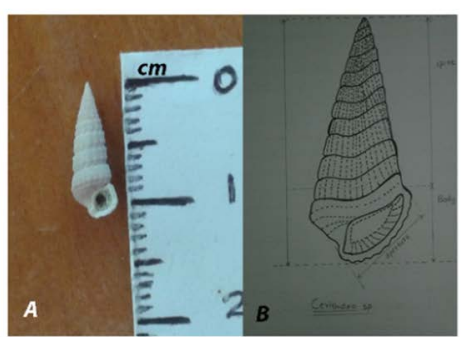

Cerithidea sp. 

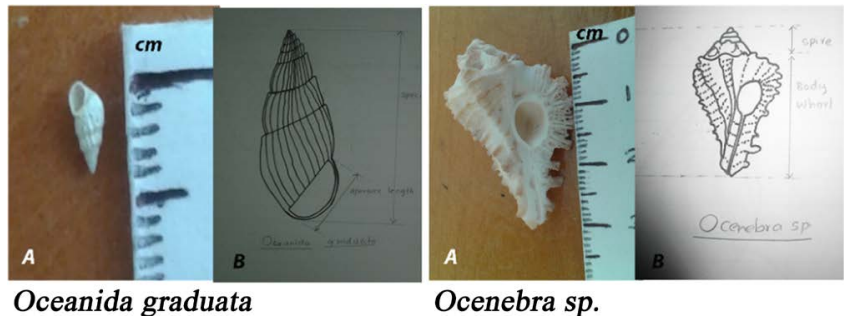

Ocenebra sp.
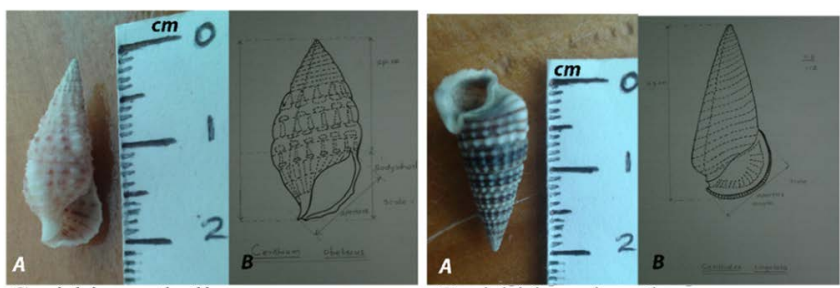

Cerithium obeliscus

Cerithidea cingulata

Figure 4. Collected gastropod species within the Thondaimanaru lagoon, (A) Photographic view, (B) Diagramatic view.

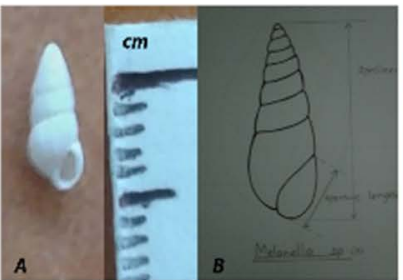

Melanella sp. (1)

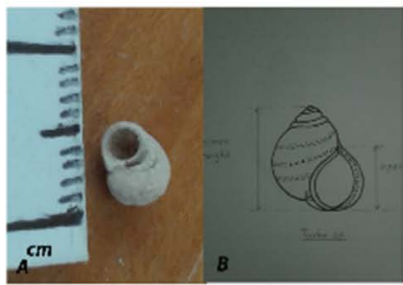

Turbo sp.

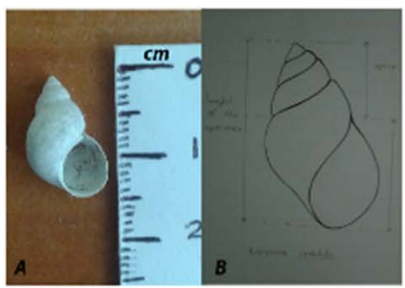

Littoraria undulata

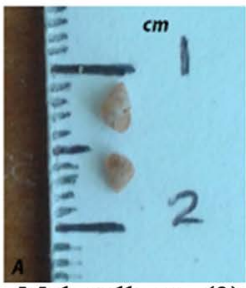

Melanella sp. (2)

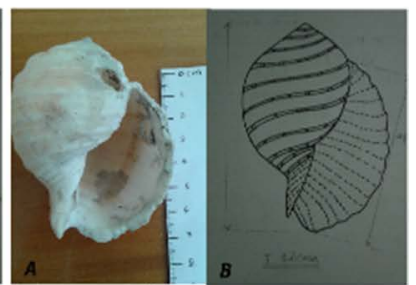

Tonna sulcosa

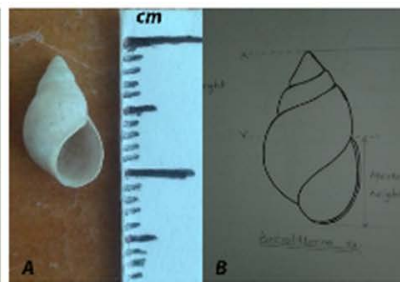

Austrolittorina sp.

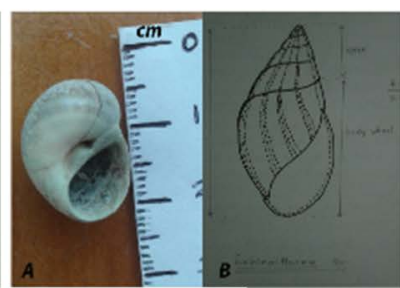

Echinolittorina sp.

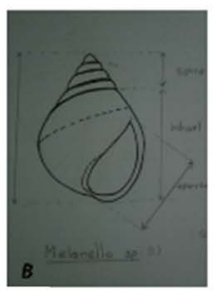

Figure 5. Collected gastropod species within the Thondaimanaru lagoon, (A) Photographic view; (B) Diagramatic view. 
$s p$. Present in Figure 4. At the same time we can consider the presence of axial ridges or not, operculum shape (round or oval) and morphometrical characteristics such as, length of the whorl, width of the aperture, Length ratios, Height of the spire and Girth diameter.

\section{Conclusion}

The study shows anthropogenic disturbances that cause ecological changes and it can be exploited by some snail species, especially family Potamididae and Cerithiidae species, while other species may not tolerate these changes. In order to protect gastropod diversity and avoid dominance of intermediate hosts, a management plan for the use of these fish landing sites should be developed. This should include rules on how to dispose of fish remnants and other wastes so as to reduce local eutrophication, thereby reducing risks associated with transmission of potential snail-borne diseases and land and water pollution within the area.

\section{Acknowledgements}

I would like to thank all the Academic and Non-academic staff of the Department of Zoology at the faculty of Science, University of Jaffna, Sri Lanka for their great assistance and company during field visits. Furthermore, I am grateful to Dr. Mrs. T. William Shanthakumar and Mrs. P. Sivakumar for their guidance and valuable comments.

\section{Conflicts of Interest}

The authors declare no conflicts of interest regarding the publication of this paper.

\section{References}

Bae, M. J., \& Park, Y. S. (2020). Key Determinants of Freshwater Gastropod Diversity and Distribution: The Implications for Conservation and Management. Water, 12, 1908. https://doi.org/10.3390/w12071908

Bieler, R. (1992). Gastropod Phylogeny and Systematics. Annual Review of Ecology and Systematics, 23, 311-338. https://doi.org/10.1146/annurev.es.23.110192.001523

Dahanayaka, D. D. G. L., \& Wijeyaratne, M. J. S. (2006). Diversity of Macrobenthic Community in the Negombo Estuary, Sri Lanka with Special Reference to Environment Conditions. Sri Lanka Journal of Aquatic Sciences, 11, 43-61.

https://doi.org/10.4038/sljas.v11i0.2222

Darwin, C., \& Padmavathi, P. (2017) Diversity of Malacofauna from the Paleru and Moosy Backwaters of Prakasam District, Andhra Pradesh, India. Journal of Entomology and Zoology Studies, 5, 881-887.

De Silva, D. (2006). Current Status of Taxonomy and Ecology of Marine Molluscs in Sri Lanka. In C. N. B. Bambaradeniya (Ed.), The Fauna of Sri Lanka: Status of Taxonomy, Research and Conservation (pp. 274-287). Colombo: The World Conservation Union.

Dissanayake, N., \& Chandrasekara, U. (2014). Effects of Mangrove Zonation and the Physicochemical Parameters of Soil on the Distribution of Macrobenthic Fauna in Ka- 
dolkele Mangrove Forest, a Tropical Mangrove Forest in Sri Lanka. Advances in Ecology, 2014, Article ID: 564056. https://doi.org/10.1155/2014/564056

Fernando, M. (2009). Shells of the Sri Lanka Sea Shore (pp. 25-122). Colombo: Bio Diversity Secretariat Ministry of Environment.

Giannelli, A., Cantacessi, C., Colella, V., Dantas-Torres, F., \& Otranto, D. (2016). Gastropod-Borne Helminths: A Look at the Snail-Parasite Interplay. Trends in Parasitology, 32, 255-264. https://doi.org/10.1016/j.pt.2015.12.002

Herath, H. M. I. M., \& Goonasekara, M. M. (2013). Land Snail Species Distribution in Selected Sites in the Northern Knuckles Region of Sri Lanka.

Moradi, S., Danehkar, A., Erfani, M., \& Ardakani, T. (2019). Gastropods Diversity in Mangrove Forests of Govater Gulf in Sistan \& Baluchestan. Journal of Wildlife and Biodiversity, 3, 36-43.

Perera, E. N. R., \& Weerakkody, P. (2004). A Biodiversity Status Profile of Sub-Tidal and Inter-Tidal Habitats of the Rekawa, Ussangoda, and Kalametiya Area. IUCN, Sri Lanka.

Piratheepa, S., Rajendramani, G., \& Eswaramohan, T. (2016). Changes in Fish and Shellfish in Thondamanaru Lagoon, Jaffna, Sri Lanka. World Academy of Science, Engineering and Technology, International Journal of Environmental, Chemical, Ecological, Geological and Geophysical Engineering, 10, 669-673.

Rosenberg, G. (1993). A Database Approach to Studies of Molluscan Taxonomy, Biogeography and Diversity, with Examples from Western Atlantic Marine Gastropods. American Malacological Bulletin, 10, 257-266.

Suominen, O., Edenius, L., Ericsson, G., \& de Dios, V. R. (2003). Gastropod Diversity in Aspen Stands in Coastal Northern Sweden. Forest Ecology and Management, 175, 403-412. https://doi.org/10.1016/S0378-1127(02)00142-1

Wijeyaratne, W. M. D. N., \& Kalaotuwawe, K. M. B. P. P. (2017). Evaluation of the Water and Sediment Quality of a Lotic Water-Body in the Western Coastal Region of Sri Lanka Using Rapid Bioassessment Protocol II (RBP II) of Benthic Macroinvertebrates. Sri Lanka Journal of Aquatic Sciences, 22, 85-97. https://doi.org/10.4038/sljas.v22i2.7533

Yadav, R., Malla, P. K., Dash, D., Bhoi, G., Patro, S., \& Mohapatra, A. (2019). Diversity of Gastropods and Bivalves in the Mangrove Ecosystem of Paradeep, East Coast of India: A Comparative Study with Other Indian Mangrove Ecosystems. Molluscan Research, 39, 325-332. https://doi.org/10.1080/13235818.2019.1644701 